\title{
Studies on Antibiotic Synergism Against Enterococci
}

\author{
II. EFFECT OF VARIOUS ANTIBIOTICS ON THE UPTAKE OF \\ ${ }^{14} \mathrm{C}-L A B E L E D$ STREPTOMYCIN BY ENTEROCOCCI
}

\author{
Robert C. Moellering, Jr. and Arnold N. Weinberg \\ From the Infectious Disease Unit and Department of Medicine, Massachusetts \\ General Hospital and Harvard Medical School, Boston, Massachusetts 02114
}

A B S T R A C T The mechanism by which agents that inhibit bacterial cell wall synthesis produce a synergistic effect against enterococci when combined with aminoglycoside antibiotics has not been elucidated. Using ${ }^{14} \mathrm{C}$ labeled streptomycin, it could be shown that uptake of this aminoglycoside antibiotic was markedly enhanced in enterococci growing in the presence of penicillin or other agents which inhibit the synthesis of bacterial cell walls. There was no enhancement of streptomycin uptake when the cells were incubated with antibiotics which primarily affect the bacterial cell membrane or inhibit protein synthesis. Increased streptomycin uptake was produced by penicillin only in actively growing bacteria. These observations are consistent with the hypothesis that enterococci exhibit a natural barrier to the entry of streptomycin which can be overcome by agents which inhibit cell wall synthesis, thus producing a synergistic effect.

\section{INTRODUCTION}

The fact that penicillin and streptomycin can act synergistically against enterococci is well known $(1,2)$. As a result, this combination has been extensively used in the treatment of enterococcal infections (3). The mechanism of penicillin-streptomycin synergism, however, has not been elucidated (4). Our previous studies have shown that antibiotics which inhibit bacterial cell wall formation (irrespective of the synthetic step blocked) produce synergism against enterococci when used in combination with streptomycin or other aminoglycoside anti-

This work was presented in part at the 9th Interscience Conference on Antimicrobial Agents and Chemotherapy, Washington, D. C., October, 1969.

Received for publication 20 May 1971 and in revised form 12 July 1971. biotics (5). On the basis of these studies we suggested that enterococci are relatively impermeable to aminoglycoside antibiotics, and that the permeability barrier can be breached by agents which inhibit bacterial cell wall synthesis. To test the validity of that hypothesis, we have studied the uptake of ${ }^{14} \mathrm{C}$-labeled streptomycin by enterococci in the presence of various antibiotics.

\section{METHODS}

Organisms. The organism used for the initial studies was an enterococcus (Streptococcus faecalis var. liquefaciens, designated strain EI) obtained from a patient with endocarditis, and has been described in detail elsewhere (5). The minimal inhibitory concentration $(\mathrm{MIC})^{1}$ of penicillin for this organism was $1 \mathrm{U} / \mathrm{ml}$ and the minimal bactericidal concentration (MBC) was $>1000 \mathrm{U} / \mathrm{ml}$. The MIC of streptomycin was $400 \mu \mathrm{g} / \mathrm{ml}$ and the $\mathrm{MBC}$ was $800 \mu \mathrm{g} / \mathrm{ml}$. Penicillin and streptomycin in combination were synergistic against this organism (5). A spontaneous mutant to very high level streptomycin resistance (MIC, MBC $>5000$ $\mu \mathrm{g} / \mathrm{ml}$, designated strain $\mathrm{EI}^{\mathrm{R}}$ ) was also studied. Penicillin and streptomycin failed to act synergistically against this mutant (5).

Antibiotics. ${ }^{14} \mathrm{C}$-labeled streptomycin (Streptomycin-Ca$\mathrm{Cl}_{2}$, specific activity $0.054 \mu \mathrm{Ci} / \mathrm{mg}$ ) was a gift from Dr. C. Rosenblum of Merck Sharp \& Dohme, West Point, $\mathrm{Pa}$. Unlabeled antibiotics were supplied to us as follows: cycloserine, erythromycin (Eli Lilly and Company); chloramphenicol (Parke, Davis \& Company); penicillin (Pfizer Laboratories Division, Pfizer, Inc.); bacitracin (Pfizer Laboratories Division and The Upjohn Company); streptomycin (E. R. Squibb \& Sons); colistin (Warner-Chilcott Laboratories).

Determination of streptomycin uptake. $1 \mathrm{ml}$ of an overnight nutrient broth culture of the test organism was added to $14 \mathrm{ml}$ of dextrose-phosphate broth (Albimini) in a 250 $\mathrm{ml}$ flask and preincubated at $37^{\circ} \mathrm{C}$ for $90 \mathrm{~min}$ to allow the organisms to reestablish rapid ("log phase") growth. At the end of this period, appropriate antibiotics were added;

${ }^{1}$ Abbreviations used in this paper: $\mathrm{MBC}$, minimal bactericidal concentration; MIC, minimal inhibitory concentration. 
and after mixing, $1 \mathrm{ml}$ samples were removed for counting and for protein determination. The flasks were then reincubated at $37^{\circ} \mathrm{C}$ and additional $1 \mathrm{ml}$ samples were removed for counting and protein determination at varying intervals (usually $15,30,60,90,120$, and $180 \mathrm{~min}$ for counting and 90 and $180 \mathrm{~min}$ for protein determinations).

The samples for counting were filtered through a $25 \mathrm{~mm}$ membrane filter (Millipore, HA $0.45 \mu$, Millipore Corp.). The samples were washed with $15 \mathrm{ml}$ of distilled $\mathrm{H}_{2} \mathrm{O}$ (or in certain instances as noted in the Results, $15 \mathrm{ml}$ of unlabeled streptomycin solution, $2 \mathrm{mg} / \mathrm{ml}$ ) and the filters dried. Filters were then placed in counting vials, with 0.2 $\mathrm{ml}$ distilled $\mathrm{H}_{2} \mathrm{O}$, and $10 \mathrm{ml}$ Buhlers solution (6) added; and the vials were counted for at least $30 \mathrm{~min}(1000-4300$ counts) on a Packard Tri-Carb liquid scintillation counter (Packard Instrument Co.). The data were corrected for background counts and for blank values obtained by filtering and washing medium containing labeled streptomycin but no bacteria. All counts (except an occasional time 0 determination) were twice background or more. Samples for protein determination were washed three times in $5 \mathrm{ml}$ volumes of distilled water and protein concentrations measured using the Lowry micromethod (7).

Streptomycin uptake by bacteria was expressed as micrograms streptomycin per milligram protein.

\section{RESULTS}

When streptomycin ${ }^{14} \mathrm{C}$ was added to a culture of growing bacteria, there was a rapid initial uptake of antibiotic by the cells, which was present at the time of first sampling, immediately after adding streptomycin. This is shown in Fig. 1. After the initial uptake, the amount of streptomycin- ${ }^{14} \mathrm{C}$ bound to the bacteria remained approximately constant for the duration of the experiment. When penicillin and streptomycin were added simultaneously, the rapid initial uptake also oc-

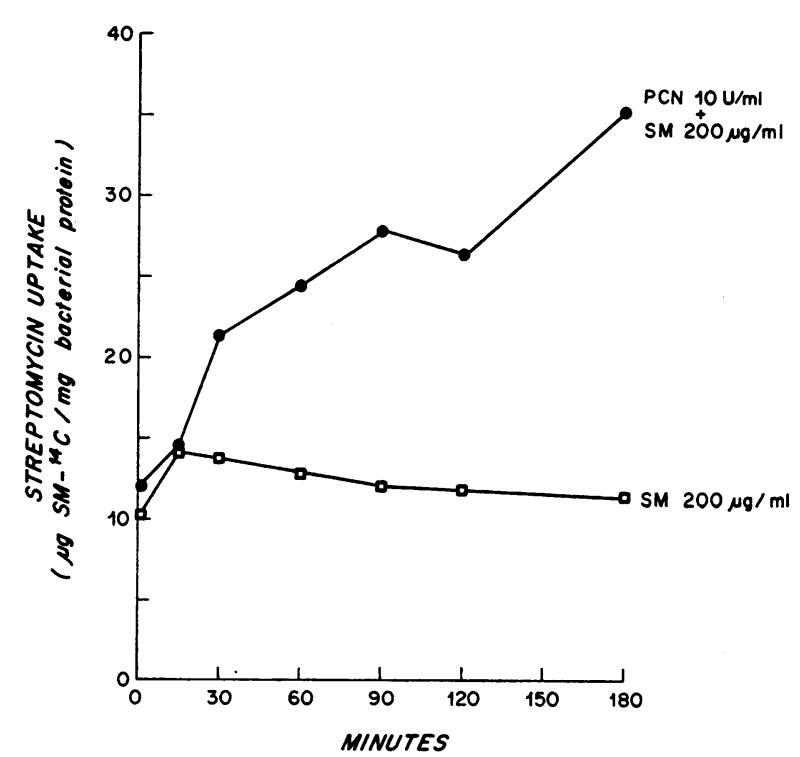

FIGURE 1 Effect of penicillin (PCN) on uptake of streptomycin ${ }^{14} \mathrm{C}(\mathrm{SM})$ by $S$. faecalis strain $\mathrm{EI}$.

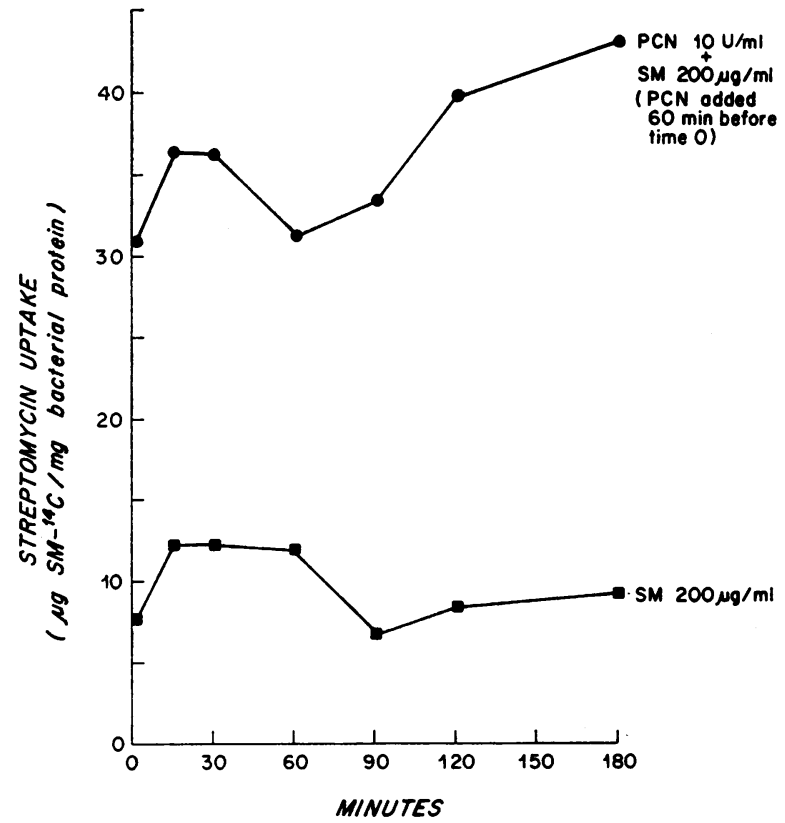

FIgURE 2 Effect of pretreatment with penicillin (PCN) on uptake of streptomycin- ${ }^{14} \mathrm{C}(\mathrm{SM})$ by $S$. faecalis strain EI.

curred, but, in addition, a marked secondary uptake of streptomycin was noted. This began approximately 30 min after the addition of the antibiotics and progressed so that after $180 \mathrm{~min}$ the amount of streptomycin $-{ }^{14} \mathrm{C}$ taken up by the bacteria in the presence of penicillin was more than three times that bound in the absence of penicillin (Fig. 1).

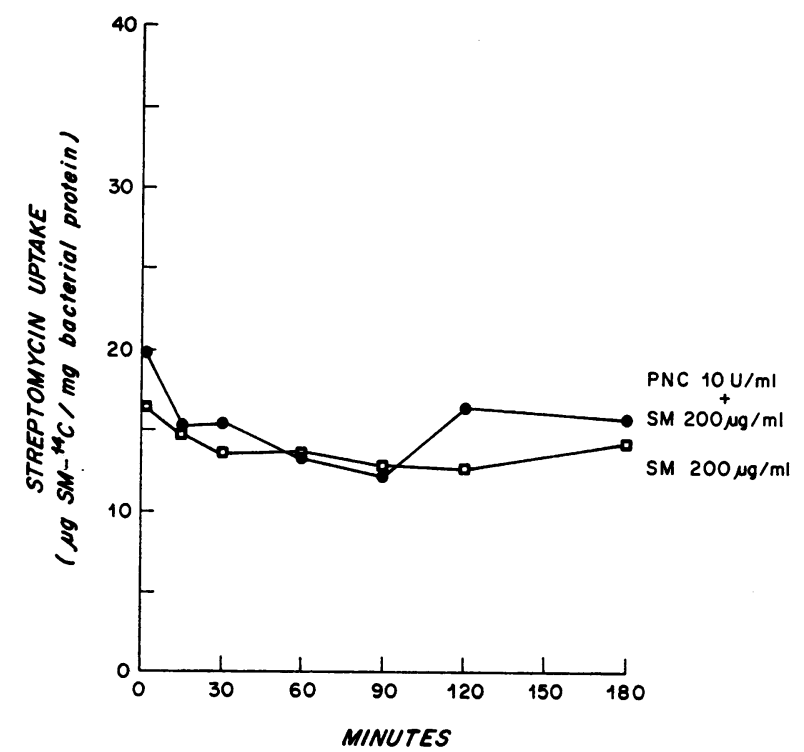

FIgURE 3 Effect of penicillin (PNC) on uptake of streptomycin-14 ${ }^{14}$ (SM) by nondividing (post "log phase") $S$. faecalis strain EI. 


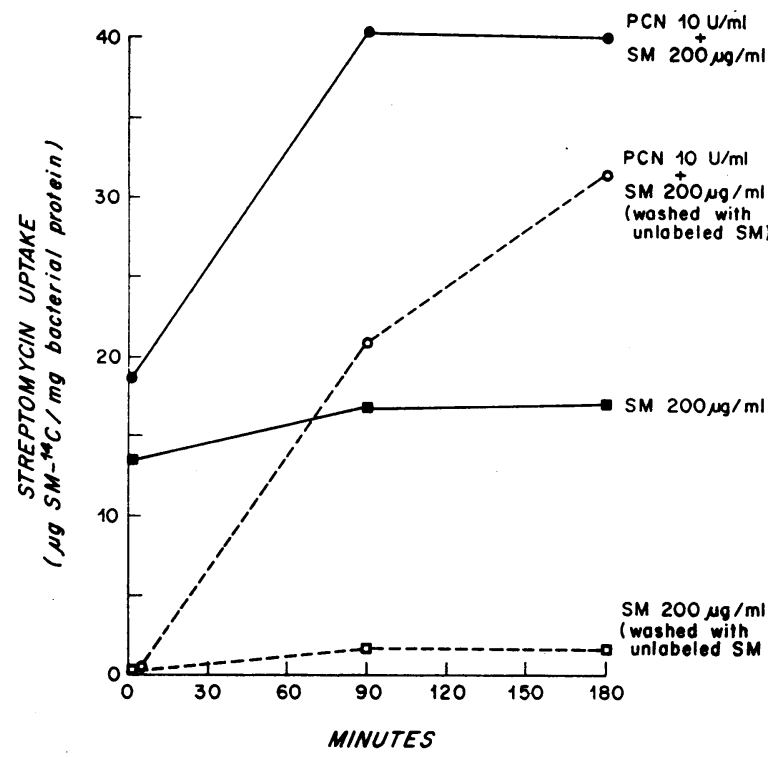

FIGURE 4 Uptake of streptomycin $-{ }^{14} \mathrm{C}$ (SM) by $S$. faecalis strain EI in the presence and absence of penicillin (PCN) : effect of washing with unlabeled streptomycin.

If the growing bacteria were pretreated with penicillin by adding this antibiotic $1 \mathrm{hr}$ before adding streptomycin $-{ }^{14} \mathrm{C}$, there was no delay in "secondary uptake" of streptomycin- ${ }^{14} \mathrm{C}$. Indeed, there was a marked increase in uptake at the time of initial sampling, as shown in Fig. 2.

To insure that the increased uptake of streptomycin${ }^{14} \mathrm{C}$ in the presence of penicillin was not due to a nonspecific increase in streptomycin affinity of the cells

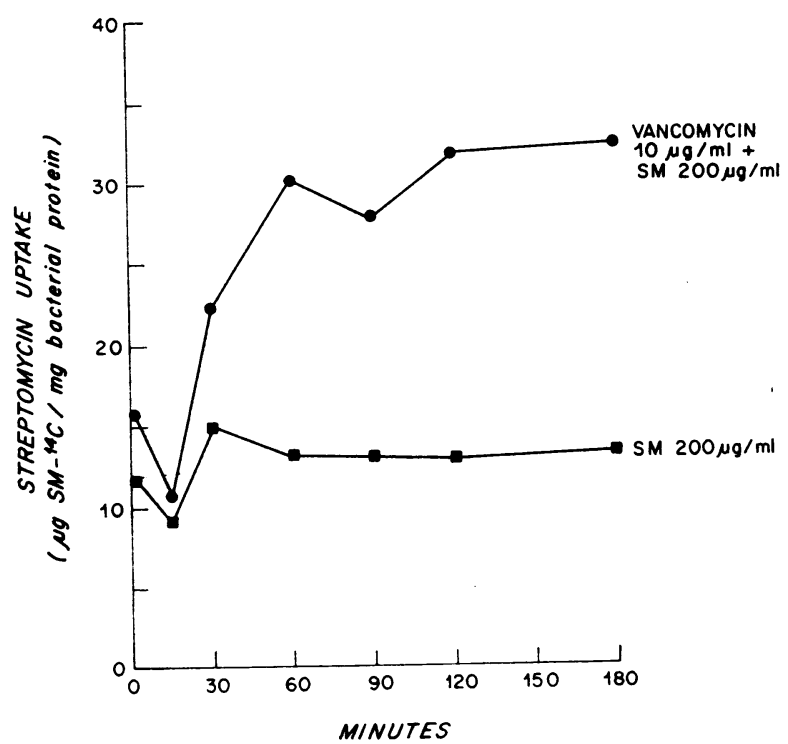

FIGURE 5 Effect of vancomycin on uptake of streptomycin${ }^{14} \mathrm{C}(\mathrm{SM})$ by $S$. faecalis strain EI. caused merely by the physical presence of penicillin, the experiments were repeated using nondividing ("post log phase") enterococci. As shown in Fig. 3, penicillin produced no increase in streptomycin uptake in nondividing cells.

To learn the reason for the rapid initial uptake of streptomycin by enterococci, irrespective of the presence of penicillin, unlabeled streptomycin was used to wash the cells. When the filtered bacteria were washed with unlabeled streptomycin instead of distilled water, virtually all of the streptomycin ${ }^{14} \mathrm{C}$ bound in the absence of penicillin could be removed as shown in Fig. 4. There was also a decrease in amount of labeled aminoglycoside bound in the presence of penicillin; but as can also be noted in Fig. 4, a significant amount of the drug remained associated with the penicillin-treated cells despite the streptomycin wash.

Our previous studies (5) have shown that other antibiotics which inhibit cell wall synthesis, including cycloserine, bacitracin, and vancomycin, produced synergism when each was used in combination with streptomycin against enterococcus strain EI. Each of these antibiotics produced an increased uptake of streptomycin- ${ }^{14} \mathrm{C}$ when substituted for penicillin in the present test system. Fig. 5 shows the results of an experiment utilizing vancomycin. Cycloserine and bacitracin (not shown) yielded similar findings.

Neither chloramphenicol, erythromycin, nor colistin caused an increased uptake of labeled drug when used in combination with streptomycin- ${ }^{14} \mathrm{C}$.

Penicillin and streptomycin did not demonstrate synergism against a mutant enterococcal strain $\left(\mathrm{EI}^{\mathbf{R}}\right)$

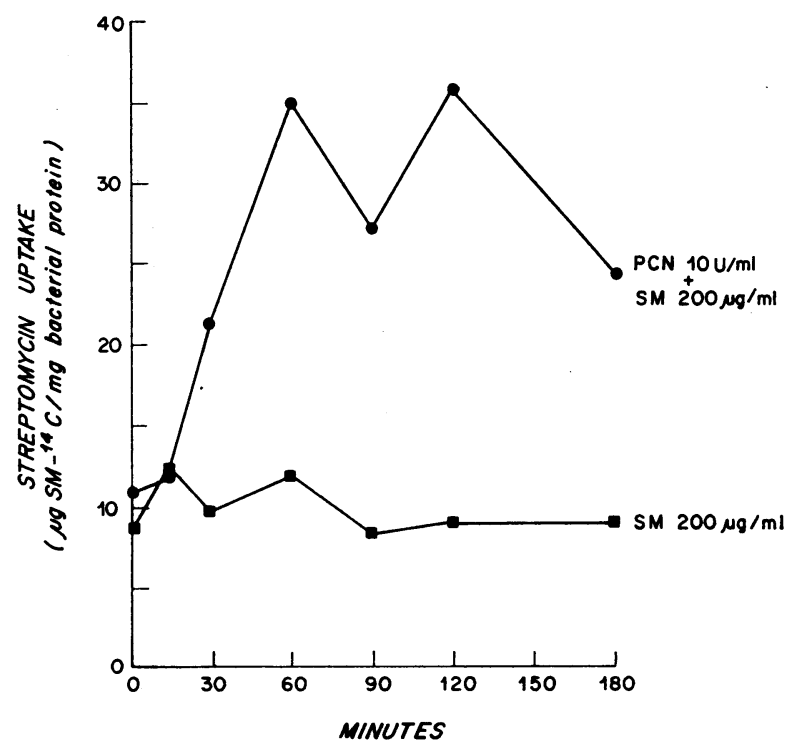

Figure 6 Effect of penicillin (PCN) on uptake of streptomycin- ${ }^{14} \mathrm{C}(\mathrm{SM})$ by $S$. faecalis strain $\mathrm{EI}^{\mathrm{R}}$, a mutant exhibiting very high level streptomycin resistance. 
which exhibited very high level resistance to streptomycin (MIC, MBC $>5000 \mu \mathrm{g} / \mathrm{ml}$ ) (5). When this strain was substituted for the parent strain in the test system (Fig. 6), penicillin again caused an increase in streptomycin ${ }^{14} \mathrm{C}$ uptake, despite the fact that increased killing did not occur.

\section{DISCUSSION}

Although penicillin and streptomycin have been widely used to treat infections caused by enterococci (1-3), the mechanism whereby these antibiotics produce a synergistic effect has not been definitely worked out (4). After an extensive investigation of this phenomenon, Hewitt, Seligman, and Deigh suggested that penicillin treatment resulted in the formation of enterococcal $\mathrm{L}$ forms which were more sensitive to streptomycin than their parent forms (8). Several other investigators have likewise shown that enterococcal $\mathrm{L}$ forms show enhanced susceptibility to aminoglycoside antibiotics $(9,10)$. However, there is no concrete evidence that a significant number of $\mathrm{L}$ forms are produced in vivo when enterococci are treated with penicillin. Furthermore, synergism occurs when growth experiments are performed in routine liquid media which do not contain the osmotic protection necessary for the survival of $\mathrm{L}$ forms; and neither erythromycin nor tetracycline (to which $\mathrm{L}$ forms are usually sensitive in vitro) produces synergism with penicillin against entercocci (5). Therefore our data suggest that synergism can occur in the absence of $\mathrm{L}$ form production.

Our previous studies (5) have suggested that the resistance of enterococci to streptomycin may be related to the fact that these organisms exhibit a natural permeability barrier to aminoglycoside antibiotics. This barrier can be overcome by using very high concentrations of streptomycin (5). We have also shown that all antibiotics which inhibit bacterial cell wall synthesis, irrespective of the synthetic step blocked, produce synergism with streptomycin against enterococci. Antibiotics which affect the bacterial cell membrane or inhibit protein synthesis fail to produce synergism with streptomycin. These studies therefore suggested that synergism occurs when penicillin or other agents which inhibit bacterial cell wall synthesis breach a natural barrier (presumably the cell wall), allowing streptomycin to enter and kill the bacteria.

The experiments reported here confirm this hypothesis. The rapid, initial uptake of streptomycin $-{ }^{14} \mathrm{C}$ by enterococci in the absence of other agents almost certainly represented nonspecific adsorption to the cell surface since it was easily and completely removed by washing with unlabeled streptomycin. The lack of a spontaneous secondary uptake of streptomycin such as has been shown to occur in Escherichia coli in the absence of penicillin (11) further suggests that enterococci are relatively impermeable to streptomycin. Penicillin and other agents which inhibit bacterial cell wall synthesis (cycloserine, bacitracin, vancomycin) clearly overcame that permeability barrier and allowed a marked secondary uptake of streptomycin. The fact that much of this streptomycin- ${ }^{14} \mathrm{C}$ could not be washed out with unlabeled streptomycin suggests that it was in an intracellular location or was bound in such a way that it was not easily accessible to displacement by the streptomycin wash.

The increased uptake of streptomycin in the presence of penicillin occurred only in actively dividing cells. This is further indirect evidence that formation of cell walls and inhibition thereof by penicillin is necessary for increased uptake of streptomycin to occur. It also shows that the increased uptake is not simply due to a nonspecific increase in binding of streptomycin by cells due to the mere physical presence of penicillin. As predicted from our previous experiments (5), agents which do not affect cell wall synthesis failed to enhance the uptake of streptomycin by enterococci.

The increased uptake of streptomycin $-{ }^{14} \mathrm{C}$ in the presence of penicillin by a highly streptomycin resistant ("nonsynergistic") enterococcal strain is of interest. This suggests that failure of synergism in this strain was not due to failure of increased streptomycin uptake, but rather to inability of the streptomycin to act once it entered the cell. Recent studies in our laboratory have shown that streptomycin failed to cause misreading or to inhibit amino acid incorporation when ribosomes from the "nonsynergistic" strain were tested in an in vitro system (12). This explains the failure of synergism of penicillin and streptomycin against the above, and other strains of enterococci which exhibit very high level resistance to streptomycin (13).

On the basis of these experiments we cannot state with absolute certainty that the formation of $\mathrm{L}$ forms plays no role in antibiotic synergism against enterococci. However, if such forms are produced, it seems likely that they too will be more permeable to streptomycin. This almost certainly accounts for the previous observations that enterococcal $\mathrm{L}$ forms are more sensitive to aminoglycoside antibiotics than their parent strains $(9,10)$.

It is not yet clear whether the phenomenon we have described is limited to enterococci. However, Plotz and Davis showed in 1962 that penicillin could increase the rate of uptake of streptomycin ${ }^{14} \mathrm{C}$ in a strain of E. coli, an effect that they attributed to damage of the cell membrane by penicillin (14). This suggests that enhanced uptake of aminoglycoside antibiotics may be induced in bacteria other than enterococci by agents 
which inhibit cell wall synthesis. If this proves to be the case, it could have significant application in the treatment of infections caused by organisms which are resistant to a large number of antibiotics when used alone.

\section{ACKNOWLEDGMENTS}

The technical assistance of Miss Christine Wennersten is gratefully acknowledged.

This work was supported by grants from The King Trust and from The Medical Foundation, Boston, Mass.

\section{REFERENCES}

1. Dowling, H. F. 1965. Present status of therapy with combinations of antibiotics. Amer. J. Med. 39: 796.

2. Jawetz, E. 1968. Combined antibiotic action: some definitions and correlations between laboratory and clinical results. Antimicrob. Agents Chemother. 203.

3. Mandell, G. L., D. Kaye, M. E. Levison, and E. W. Hook. 1970. Enterococcal endocarditis.. Arch. Intern. Med. 125: 258.

4. Sabath, L. D. 1968. Synergy of antibacterial substances by apparently known mechanisms. Antimicrob. Agents Chemother. 210.

5. Moellering, R. C., Jr., C. Wennersten, and A. N. Weinberg. 1971. Studies on antibiotic synergism against enterococci. I. Bacteriologic studies. J. Lab. Clin. Med. $77: 821$.
6. Buhler, D. R. 1962. A simple scintillation counting technique for assaying $\mathrm{C}^{14} \mathrm{O}_{2}$ in a Warburg flask. Anal. Biochem. 4: 413 .

7. Lowry, O. H., N. J. Rosebrough, A. L. Farr, and R. J. Randall. 1951. Protein measurement with the Folin phenol reagent. J. Biol. Chem. 193: 265.

8. Hewitt, W. L., S. J. Seligman, and R. A. Deigh. 1966. Kinetics of the synergism of penicillin-streptomycin and penicillin-kanamycin for enterococci and its relationship to L-phase variants. J. Lab. Clin. Med. 67: 792.

9. Shockman, G. D., and J. O. Lampen. 1962. Inhibition by antibiotics of the growth of bacterial and yeast protoplasts. J. Bacteriol. 84: 508.

10. Montgomerie, J. Z., G. M. Kalmanson, and L. B. Guze. 1968. The susceptibility of protoplast and bacterial forms of Streptococcus faecalis to antibiotics. In Microbial Protoplasts, Spheroplasts, and L-forms. L. B. Guze, editor. Williams \& Wilkins Co., Baltimore. 306.

11. Anand, N., B. D. Davis, and A. K. Armitage. 1960. Uptake of streptomycin by Escherichia coli. Nature (London). 185: 23.

12. Zimmermann, R. A., R. C. Moellering, Jr., and A. N. Weinberg. 1971. Mechanism of resistance to antibiotic synergism in enterococci. J. Bacteriol. 105: 873.

13. Standiford, H. D., J. B. deMaine, and W. M. M. Kirby. 1970. Antibiotic Synergism of Enterococci. Arch. Intern. Med. 126: 255.

14. Plotz, P. H., and B. D. Davis. 1962. Synergism between streptomycin and penicillin: a proposed mechanism. Science (Washington). 135: 1067. 